Bernadette Van

Haute

Department of Art

History, Visual Arts and Musicology, University

of South Africa, PO

Box 392, 0003 UNISA;

E-mail: vhautbmr@

unisa.ac.za

DOI: http://dx.doi. org/10.18820/24150479/ aa48i2.1

ISSN: ISSN 0587-2405

e-ISSN: 2415-0479

Acta Academica $\cdot 2016$

48(2): 18-47

(c) UV/UFS

\section{Anthony Van Dyck and the trope of the black attendant}

First submission: 15 April 2016

Acceptance: 27 October 2016

This article examines Van Dyck's use of the motif of the African attendant in his extant oeuvre in order to establish patterns and strategies of representation of the racial other. It reveals the artist's paternalistic interpretation of a trope that was aesthetically informed by examples set by Titian and Rubens but adapted to the tastes of his patrons as determined by the fashion of the time and place. By considering the iconography in conjunction with the reception of the works I disclose the varying connotations of the motif demonstrating the artist's wit in developing early visual forms of racial humour. These unique adaptations expose Van Dyck's use of ridicule as a pattern of paternalism rooted in his social ambitions and Christian convictions yet always subject to the conditions of display. The value of this research lies in its contribution both to Van Dyck scholarship and to the history of race and racism in early modern Western Europe. 


\section{Introduction}

Anthony Van Dyck is rightfully recognised as the artist who established the motif of the black servant as a secondary figure in $17^{\text {th }}$-Century portraiture (Kaplan 2010:180). The presence of the black African in his history paintings, on the other hand, has received scant attention. In this article I examine Van Dyck's use of the motif of the African attendant in his extant oeuvre in order to establish patterns and strategies of representation of the visibly different, racial other. From an art historical perspective my aim is to reveal the artist's unique interpretation of a trope that was informed by examples set by Titian and Rubens but adapted to the tastes of his patrons as determined by the fashion of the time and place. By considering the iconography in conjunction with the reception of the works I intend to disclose the varying connotations of the motif demonstrating the artist's wit in developing early visual forms of racial humour. In my view these adaptations reveal Van Dyck's ambivalent perception of black Africans rooted in his social ambitions and Christian convictions yet always subject to the conditions of display.

Because the concept of colour is present here as an ethnic marker (Erickson 2000:315), the ambivalent attitude of Van Dyck needs to be explored in light of contemporary critical race theories - but with specific focus on the European experience of blackness. Dienke Hondius (2014:2) points out that "because Europe lacked a significant black community, different forms of stereotyping and blackness developed" when compared "with the American history of race relations". "In line with the notion that definitions of race vary according to time and place I select as theoretical framework the new thesis of Hondius's expounded in her book Blackness in Western Europe: Racial patterns of paternalism and exclusion (2014). Hondius (2014:2) argues that paternalism, as the most pervasive pattern of behaviour in European race relations, "dominates European racial discourses". She conceives of racial paternalism as a theory that explains the power structures between white Europeans and non-white Africans. It is a concept that assumes superiority on the part of white Europeans who perceive black Africans as inferior. She identifies five patterns of paternalism that characterised relations between white Europeans and black Africans: infantilisation, exoticism, bestialisation, exclusion and distancing, and exceptionalism (Hondius 2014:3-5).

1 Since interracial experiences in the United States differed vastly from those in Europe (Hondius 2014:6-12), it follows that most American scholarship on race and racism does not suit the purposes of this research. For a comparison between American and European studies of race, slavery and slave trade, see Hondius, Chapter 1 (Paternalism, race and racism in European history) (2014:15-57). 
Taking the concept of paternalism one step further, I argue that Van Dyck used humour to cloak his patronising attitude towards black Africans. J. Douglas Stewart (1990:69) first noted Van Dyck's "considerable sense of humour" displayed in his use of symbols and allusions. The type of humour encountered in the group of paintings selected here is termed ethnic or racial humour. According to Christie Davies (1982:383), "ethnic jokes delineate the social, geographical and moral boundaries of a nation or ethnic group. By making fun of peripheral and ambiguous groups they reduce ambiguity and clarify boundaries or at least make ambiguity appear less threatening." In line with this theory, Van Dyck can be identified as a member of the central ethnic group, namely the European elite, which upheld certain social and moral standards and, in the smaller circle of Flanders, supported the Counter-Reformist efforts of the Brussels court. The black Africans, on the other hand, were considered by this central group as ambiguous outsiders who had come to Europe, even though in limited numbers, as nonChristian slaves or servants. The moral boundaries of the European elite defined what was acceptable behaviour of its members and what was transgressive behaviour characteristic of the outsiders. The role of humour is to "police these boundaries" by mocking the unacceptable behaviour of the ambiguous other (Davies 1982:384). Hence the artist would portray the black attendant with traits that he would not wish to recognise among his peers. Racial humour or ridicule can thus be identified as a sixth pattern of paternalism aimed at making a fool of the black African. ${ }^{2}$

Since the specificities of time and place are decisive factors that shape ideas about race (Hondius 2014:328-30), it is crucial to consider that Van Dyck grew up in the Southern Netherlands where the black presence was very small (Van Haute 2015:18-20), involvement in the slave trade and slavery was nonexistent and where Roman Catholicism - which had a policy of more openness to welcoming "outsiders" compared to Protestant Christianity (Hondius 2014:150-51) - enjoyed zealous support. The young Van Dyck was introduced to the representation of black figures in the workshop of Rubens where he was employed on several occasions between 1615 and 1620 as an assistant (Van der Stighelen 1994:29; Held 1994:70-71). It can be assumed that he was present at the modelling session when Rubens made his Four Studies of the Head of a Black Man in 1615 (Van Haute 2015:25-30). The Getty picture of the same title ${ }^{4}$ may indeed

2 Referring to the writings of Frantz Fanon, Hondius (2014:99-100) only briefly mentions ridicule as a form of objectification "which ties in with infantilization".

3 Peter Paul Rubens, Four Studies of the Head of a Black Man (ca. 1615). Oil on wood transposed onto canvas, $51 \times 66 \mathrm{~cm}$. Royal Museum of Fine Arts of Belgium, Brussels.

4 Workshop of Rubens, Four Studies of the Head of a Black Man (ca. 1615). Oil on wood, 25,4 x 64,8 cm. J. Paul Getty Museum, Malibu. 
have been Van Dyck's first attempt at making a head study of black models. This shows that he met black people in Rubens's studio and engaged with them as models. His personal encounter with black Africans led in the first place to a certain fascination with the aesthetic possibilities of colour effects (Erickson 1993:502). Moreover, it awakened a preoccupation with African people as representatives of a vastly different culture which encouraged his exploration of the expressive possibilities of the cultural other. In my view this early experience in Rubens's studio had a decisive influence on his subsequent portrayals of black Africans in his early history paintings and portraits. As will be shown in the artworks discussed below Van Dyck displayed remarkable wit in visualising various undesirable traits which betray his paternalistic attitude.

\section{History paintings}

The first painting by Van Dyck in which a black attendant appears ${ }^{5}$ is his Drunken Silenus (Fig. 1) executed around 1620 in Antwerp. It became part of the collection of Archduke Leopold Wilhelm while he was governor of the Southern Netherlands in Brussels (Barnes et al. 2004:83). The theme is derived from Ovid's Metamorphoses (11, 85-193) and refers to an episode from the Midas story (Wheelock et al. 1990:106) when Silenus was once captured by Phrygian peasants and led before King Midas (McGrath 2008:202). The composition is clearly based on Rubens's painting of the same subject as he conceived it in his workshop around 1617-18. ${ }^{6}$ Van Dyck maintained the central image of the drunken Silenus, depicted knee-length as an old, bearded, corpulent man wavering to the left, in the company of a group of revellers including an Ethiopian. Yet he deviated from Rubens in what Susan Barnes calls a "decidedly competitive twist ... display[ing] a different technique, a different cast of characters and an altogether different mood" (Wheelock et al. 1990:106).

The change in characters is reflected not only in Silenus, whose thighs are covered with hair, but particularly in the young bacchante on the left "whose long, flowing hair and wide-eyed gaze hint at the frenzy for which the maenads were known" (Wheelock et al. 1990:106). Moving to the right the rest of the cast consists of a bearded man gulping down the wine from an earthenware jug which he lifts in his right hand. Next to him stands a dark-skinned bearded figure who sticks out his tongue as he fixes his sight on the pitcher, longing for a sip of wine.

5 Around 1617 Van Dyck worked on the painting of Ulysses Discovers Achilles among the Daughters of Lycomedes (oil on canvas, $246 \times 267 \mathrm{~cm}$. Prado, Madrid). Since he executed the painting after a design by Rubens who entirely retouched it (Barnes et al. 2004:81), it does not form part of the present investigation.

6 Peter Paul Rubens, Drunken Silenus (ca. 1617-18). Oil on panel, 205 x $211 \mathrm{~cm}$. Alte Pinakothek, Munich. Rubens enlarged the original composition at the bottom and the sides in about 1626 to its current form (Wheelock et al. 1990:106). 


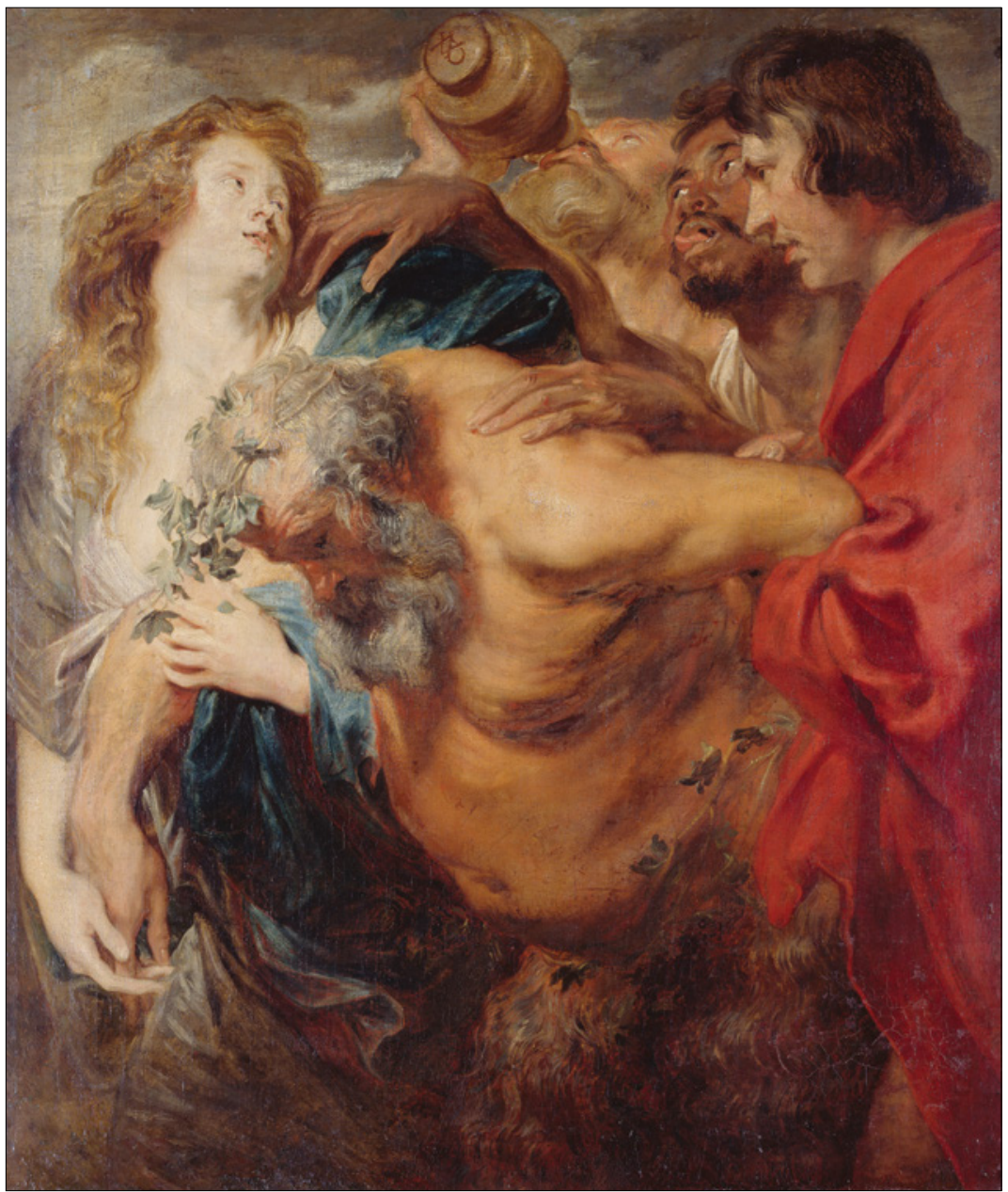

Fig. 1: Anthony Van Dyck, Drunken Silenus (ca. 1620). Oil on canvas, 107 x 91,5 cm. Monogrammed on the pitcher: AVD. Gemäldegalerie Alte Meister, Staatlichen Kunstsammlungen, Dresden, 1017. (c) bpk, Berlin.

His inebriated state is made clear by the fact that he leans heavily on the already slumping Silenus, placing his long-fingered hand on Silenus's naked shoulder. His right hand clutches the dark blue cloth which has slipped from Silenus's back towards the nymph whose cheek he touches in the process. On the extreme right appears a young man whose nakedness is covered by a red cloth 
and who stares intently at the beautiful bacchante on the opposite side. Although no external signs are visible to identify the youth as a satyr ${ }^{7}$ his countenance reveals a different nature.

As far as the mood is concerned, Barnes noted a change due to the presence of the young woman on the left who lends both a tender and erotic dimension to the painting. She maintains that the maenad, while caring for Silenus by supporting him gently, is also the "willing object of desire" of the men in the god's trail (Wheelock et al. 1990:106). McGrath (2008:202) takes this a step further, commenting that the notion of the drunken Silenus is subverted by the erotic charge taking place between the Ethiopian and the nymph. However, the black man is not looking at the nymph nor is she gazing at him: both have their eyes fixed on the jug of wine, the ultimate focus of this composition. The artist made this abundantly clear by inserting his interlocked monogram on the bottom of the upturned jug.

It has been stated that Van Dyck focused on the emotional content of the scene by a sensitive approach to gestures and facial expressions (Wheelock et al. 1990:108). When following the gazes and assessing the touches it becomes clear that the theme of drunkenness remained the artist's priority. The flailing hands merely underscore the loss of balance caused by the excessive intake of alcohol. This is not to say that there is no erotic dimension: the intensity with which the youth in red - not the Ethiopian -stares at the maenad unmistakably betrays sexual desire. By allowing the consequences of excessive drinking in the form of sexual licentiousness to filter through Van Dyck rendered the scene even more enticing.

On the other hand, his treatment of the black man sticking out his tongue is far from sensitive. There is no subtlety in this portrayal of drunken thirst: it is a very basic and physical expression of behaviour which typifies the man as uncouth and uncivilised. ${ }^{8}$ This approach is comparable to the depiction of the peasant in genre painting popularised by Pieter Brueghel the Elder in the $16^{\text {th }}$ Century. The social function of the peasant genre was to satirise the lower classes and rustics for the amusement of an urban elite (Van Haute 1999:20-21). In the same way that peasants were presented as exemplars of human depravity, carnality and foolishness, the black man exemplifies the ethnic other whose excessive and coarse behaviour elicits laughter because it is a deviation from social norms (Meyer 2000:320). The use of the black man as a comic element is an additional feature that sets Van Dyck apart from Rubens. The latter also used the black attendant in his depiction of the drunken Silenus but he never went so far as to

$7 \quad$ McGrath (2008:202) claims that no young satyrs are present in Van Dyck's scene.

8 Paul Kaplan (2015) notes that "sticking out the tongue had long been a gesture of obscene disrespect in European culture". I thank Paul Kaplan for sharing his manuscript. 
ridicule the man by making him act in a demeaning manner (Van Haute 2015:25). In more sympathetic fashion Rubens preferred to portray the Ethiopian as a satyr who grins mischievously as he playfully pinches the thigh of Silenus. Van Dyck thus alters the mood more poignantly by displaying a penchant for satire which can be read as paternalistic behaviour.

The motif of the black attendant appears again in The Continence of Scipio (Fig. 2), a theme belonging to ancient history. Van Dyck painted this work during a brief stay in England at the court of James I, from October 1620 to February 1621 (Barnes et al. 2004:136). It was in all probability made for the Duke of Buckingham ${ }^{9}$ and was recorded in the 1635 inventory of pictures at York House as hanging "in the Hall: Vandyke - One great Peice being Scipio" (Jervis 1997:57). The picture illustrates the moment when, after capturing New Carthage, the young Publius Cornelius Scipio Africanus was presented with a beautiful maiden as a prize of war. Learning that the girl was betrothed to the Celtiberian chieftain Allucius he returned her unharmed to her fiancé. The bride's parents brought a ransom of golden vessels but Scipio gave it to Allucius as a wedding gift. The story is an illustration of the virtues of statesmanship, chastity and justice (Barnes et al. 2004:135). Temperance is another virtue alluded to in the form of the foreshortened elephant seen in the rug beneath the feet of Allucius and his betrothed (Stewart 1990:70). Various attempts have been made to link the subject matter of the painting to people and events at the Jacobean court, including the Earl of Arundel, the Duke of Buckingham and King James I (Barnes et al. 2004:136). One motif adds yet another dimension to these readings.

Among the attendants bearing the gold for the girl's ransom is an African servant with nude torso carrying a casket under his left arm. In this instance the black man has a smile on his face and looks out at the viewer. Moreover, he extends his right arm towards the girl's skirt, so close that his hand nearly touches her left hand with which she has gathered up her skirt. The very fact that he looks at the viewer turns him into a commentator on the scene depicted, adding a theatrical quality. Placed opposite Scipio at the other side of the painting the black servant functions as the exact opposite of the virtuous statesman: by reaching for the girl's skirt at the height of her bottom and making a provocative gesture with his long fingers he seems to personify the vice of lustfulness.

Here Van Dyck relied on the stereotyping of the black man as a womaniser to comment on and offset the uprightness and chastity of the Roman general. The sexual stereotyping of people of dark skin colour was rather current in literature.

9 His patronage is deduced from the fact that it was the Duke's brother, John Villiers, Viscount Purbeck, who had Van Dyck sent to London (Wheelock et al. 1990:126). 


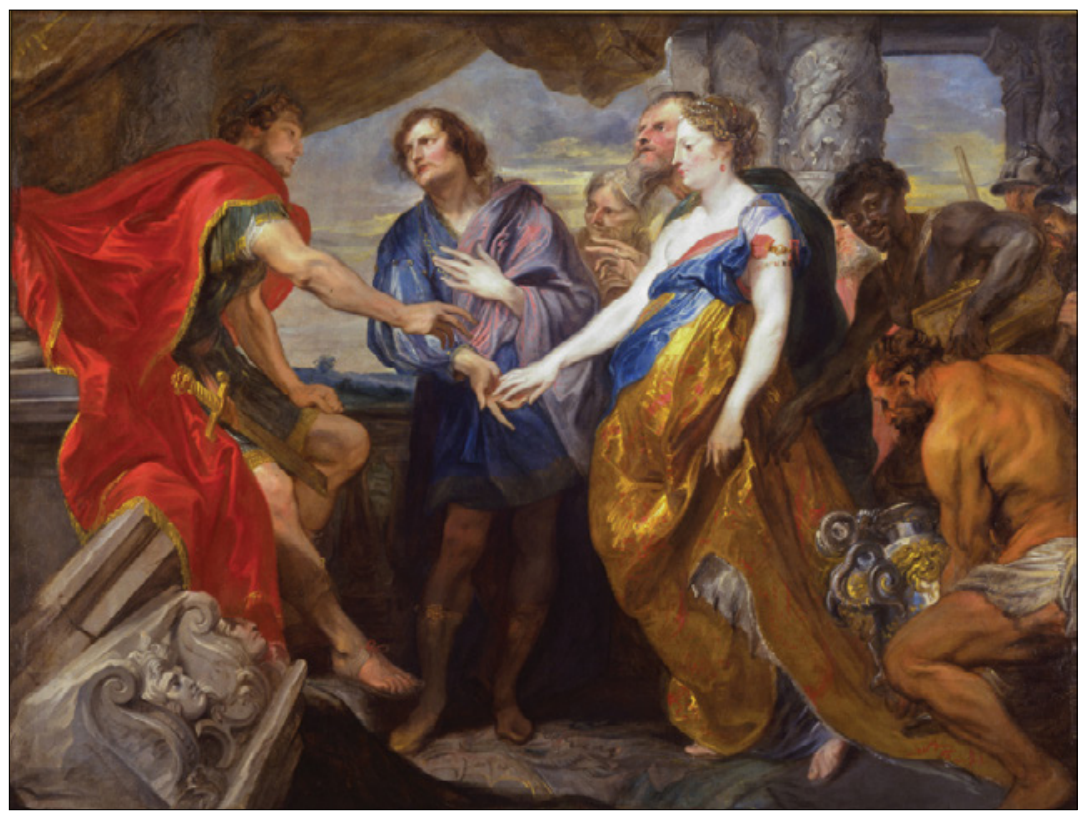

Fig. 2: Anthony Van Dyck, The Continence of Scipio (ca. 1620-21). Oil on canvas, $183 \times 232,5 \mathrm{~cm}$. Christ Church Picture Gallery, Oxford, JBS 245. By permission of the Governing Body of Christ Church, Oxford.

For example, the association of black people with love and sexuality had already appeared in the 1617 play Moortje (Little Moor) by G. A. Bredero in the following lines: "I've been told and taken it to heart, That the Moors are inclined toward the ladies for their part" (quoted in Blakely 1993:172). This is not the only instance in which Van Dyck linked a black figure to the notion of love. In 1672 the art critic Bellori described a painting by Van Dyck (now unknown or lost) as representing "a lady in the guise of Venus beside an Ethiop". 10 Seeing that Bellori explicitly characterised the comparison between black and white as comic (Kaplan 2015), it can be deduced that Van Dyck intended the motif of the grinning black man as a humorous anecdote spicing up the narrative.

10 Giovan Pietro Bellori, Le vite de' pittori, scutori e architetti moderni, ed. Evelina Borea (Turin: Einaudi, 1976), 281: "Colorí una dama in forma di Venere appresso uno etiope, la quale si rimira nello specchio e ridendosi di quell negro fa paragone della sua bianchezza" (Kaplan 2015, note 29). 
Furthermore, this adaptation of the motif betrays a particular facet of the artist's character. Julius Held (1994:63-64) describes Van Dyck as a man who not only lived "the life of a cavalier and engage[d] in conspicuous consumption" but was also known for his "sexual appetite". Given this inclination he did not shy away from giving visual expression to rather risqué and sexually explicit imagery. In an earlier painting of Samson and Delilah" a graphic allusion to the sources of Samson's undoing - namely drunkenness and lust - appears in the form of a golden pitcher, the handle of which takes the shape of an ithyphallic satyr (Stewart 1990:70). Likewise Van Dyck's patron, George Villiers, then marquess (later the first duke) of Buckingham, was not a demure person. Barnes recounts that as the darling of King James I he became the most powerful and one of the richest men at the English court whose shifting alliances and reckless initiatives eventually led to his assassination in 1628. His "legendary daring in public life" (Wheelock et al. 1990:126) was matched by a rather unconventional taste in art. Around the time that Van Dyck was working on The Continence of Scipio, George Villiers commissioned him to paint a portrait of himself and his wife Lady Katherine Manners in the guise of Venus and Adonis. ${ }^{12}$ In this portrait historie the models are depicted naked except for fluttering drapery covering strategic parts of their bodies but Lady Katherine's breasts are candidly exposed. Given the daring nature of such a portrait one might surmise that Van Dyck was encouraged by his English patron to push the boundaries of moral conventions in visual imagery.

Although blacks are rarely encountered in early $17^{\text {th }}$-Century British art there was a strong literary culture in the form of plays, poetry and courtly masques which ensured the emergence of a range of literary discourses involving Africa and its people. The most famous court masque was The Masque of Blackness performed in 1605 for James l's queen, Anne of Denmark (Bindman 2010:240). Its main trope is the transition from darkness to light, from blackness to pure beauty. Africa was seen as a dark land "without the light of benign monarchy, with little Christianity and no arts", hence African blackness was associated with barbarism and false religion (Bindman 2010:243, 245-46). The trope of whiteness as virtue and darkness as vice was thus firmly established by the time Van Dyck arrived at the court of James I and may have inspired his choice of iconography for The Continence of Scipio. The sexual allusion in the form of a lecherous black attendant would certainly have been understood and appreciated by the Duke of Buckingham.

11 Anthony Van Dyck, Samson and Delilah (1619-1620). Oil on canvas, $149 \times 229,5 \mathrm{~cm}$. Dulwich Picture Gallery, London (Wheelock et al. 1990:103-05, cat. no. 11).

12 Anthony Van Dyck, Sir George Villiers and Lady Katherine Manners as Adonis and Venus (late 1620 -early 1621). Oil on canvas, $223,5 \times 160 \mathrm{~cm}$. Harari \& Johns Ltd., London (Wheelock et al 1990:124-26, cat. no. 17). 
Shortly afterwards in 1621 (Robels 1989:399) - probably between March and October 1621 when he was in Antwerp (Wheelock et al. 1990:75) - Van Dyck collaborated with Frans Snyders on a large painting of a Fish Market (Fig. 3). The left section consisting of a fish stall with an impressive display of fish, shellish and other sea creatures was executed by Snyders while Van Dyck painted the group of life-sized figures on the right. Here an effeminate person swathed in a luxurious pink cloth over a white flimsy undergarment is seen handing a coin to the bearded fish seller in exchange for a small fish. The transaction draws the attention of a crowd of curious bystanders. They are men of different ages and colour and one old woman standing behind the fish merchant. Until the present day the scene has not been interpreted in a satisfactory manner.

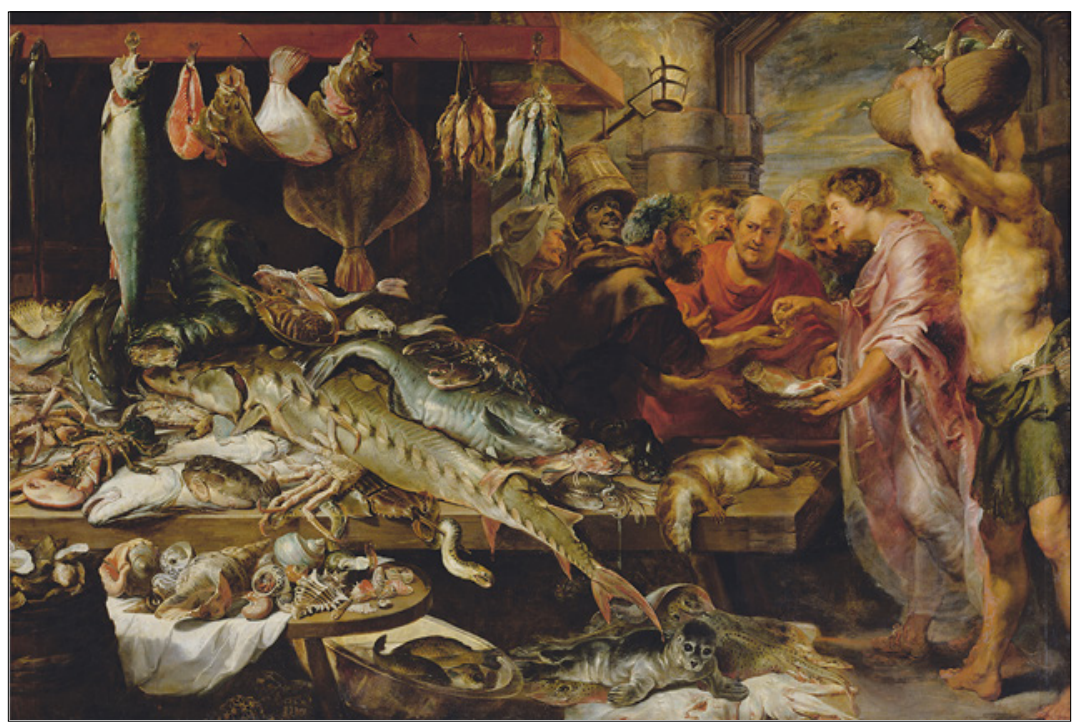

Fig. 3: Frans Snyders and Anthony Van Dyck, Fish Market (ca. 1621). Oil on canvas, $253 \times 375 \mathrm{~cm}$. Kunsthistorisches Museum, Gemäldegalerie, Vienna, 383. KHMMuseumsverband.

Just like The Continence of Scipio the painting formed part of the collection of the Duke of Buckingham but was recorded in his posthumous inventory of 1635 as a work by Rubens. It is described as hanging in the Gallery of York House and representing "A great Piece wth: Fishes" (Jervis 1997:61). Underneath this entry in the inventory appears the description of another work by Rubens as "Two of the Evangelists". A misreading of the two entries as one resulted in the subsequent conflation of the two paintings. This perpetuated the idea that the Fish Market 
represented a scene from the New Testament. ${ }^{13}$ Hella Robels (1989:399), for example, also recognises the scene as a biblical event on account of the dress of the main figures. Acknowledging another reading of the scene as the calling of Matthew (Matt. 9:9), she is more inclined to accept the suggestion that the event relates to Peter's finding of the tribute money (Matt. 17:24-27).

Despite the classical garb of the figures Susan Koslow does not accept this biblical reading. Even though the fish stall is merely a fictive evocation of the fish trade, she argues, it pays tribute to the richness of the southern Netherlands, the abundance of the products of the water and implicitly to the politics of peace pursued by the Archdukes (Koslow 1995: 133, 138, 140-42). Seeing that the painting was produced during the Twelve Years Truce when Flemish fishermen were not limited to local waters, its iconography may indeed celebrate the resurgence of the fishing industry by showing large quantities of fish and shellfish captured in the ocean (Koslow 1995:141). Another suggestion of Koslow's is that since tradition associates the representation of meat and fish markets with the notion of voluptas carnis (carnal pleasures), there may be lurking certain sexual connotations. She notes that Frans Snyders was inventive in the representation of figures and living animals in his stalls, often adding a clue to the symbolism of the painting (Koslow 1995:128, 130). In this case Snyders has included a black cat - a well-known symbol of lust - lurking beneath the bench, focusing on an eel which lifts its head in anticipation of pending danger. Even if the idea of love may seem plausible in the context of fish ${ }^{14}$ it is not clear how the narrative relates to love.

The scene is probably not biblical given the fact that the main figure purchasing the fish is beardless and, judging by the type of dress, even ambiguous in gender - hardly the image of a disciple. Most likely it relates to an event of secular history but the precise subject remains elusive..$^{15}$ What can be recognised in the scene, however, are some elements which Van Dyck borrowed from Rubens. Robels (1989:138) maintains that Van Dyck invented the composition following the example set by Rubens and Snyders in their collaborative project of The Recognition of Philopoemen. ${ }^{16}$ In terms of iconography, however, there is a closer relationship between the Fish Market and Rubens's painting of Diogenes

13 In the list of pictures being sent for sale in 1648 the painting is described as "A fish market wherein our Saviour and several other large figures are painted" (Fairfax 1758:15, no. 6).

14 References to Venus as the goddess of love may be present in the form of the sea creatures which recall her birth from the sea. The flaming torch - to kindle love - is also one of her many attributes (Hall 1987:318).

15 I wish to express my deepest gratitude to Elizabeth McGrath (email 11 January 2015) for her detailed feedback and sobering criticism.

16 Peter Paul Rubens and Frans Snyders, The Recognition of Philopoemen (ca. 1610). Oil on canvas, $201 \times 311 \mathrm{~cm}$. Prado, Madrid (Held 1980:375). 
Looking for a Man. ${ }^{77}$ The motifs of the person carrying a basket on the head and the laughing black man seen on the right in Rubens's work are incorporated in the Fish Market. Moreover, as in the story of the Greek philosopher Diogenes searching for an honest man, the setting in the Fish Market is a market place in broad daylight (Hall 1987:104) yet a bright fire - like the lamp carried by Diogenes - is lit in the street lantern seen at upper right.

In this work, however, Van Dyck has turned the black onlooker into a kind of jester who has pulled an overturned basket over his head. His eyes flaring, he even bares his teeth in uncontrolled laughter. ${ }^{18}$ As such this is the artist's most satirical rendition of the black attendant, bordering on caricature. The black man's behaviour appears to have been caused by the actions of the main figures. Some of the other onlookers also follow the proceedings with amusement such as the smiling old woman behind the fish seller and the laughing half-naked man on the extreme right balancing a full basket on his head. Whatever the precise subject of the scene, it seems to be a story with a comical twist that could titillate the imagination of a discerning collector like the Duke of Buckingham. In line with The Continence of Scipio it is probable that Van Dyck incorporated the trope of the laughing black attendant in the Fish Market as a subversive element in order to enhance the moral of the story.

\section{Religious themes}

Examples of religious themes featuring a black attendant are Van Dyck's two versions of Saint Sebastian Bound for Martyrdom, the one in Edinburgh (Fig. 4) and the other in Munich. ${ }^{19}$ Interestingly none of the Sebastian painting's "has a provenance linking it to a church" (Eaker 2015:181). Legend has it that when Sebastian, an officer of the Praetorian guard in the time of Diocletian ( $3^{\text {rd }}$ Century), revealed to be a Christian he was ordered to be shot with arrows (Hall 1987:276). The artistic convention was to portray Sebastian as a solitary figure, his body pierced with arrows as seen in Rubens's version of Saint Sebastian. ${ }^{20}$

17 Studio of Peter Paul Rubens, Diogenes Looking for a Man. Oil on canvas, $198 \times 249 \mathrm{~cm}$. Louvre, Paris, inv. 2130. The original, dateable to ca. 1613-15, is only known from a sketch of uncertain authenticity in Frankfurt (Held 1980:373-74).

18 This illustrates Plato's notion that laughter is an emotion that overrides rational self-control (Morreal 1987:10).

19 Anthony Van Dyck, Saint Sebastian Bound for Martyrdom (ca. 1621). Oil on canvas, $229 \times 159 \mathrm{~cm}$. Bayerische Staatsgemäldesammlungen, Munich. The Edinburgh version was painted before the Munich picture which differs only in the placement of the horseman and the shape of the loincloth (Barnes et al. 2004:63).

20 Peter Paul Rubens, Saint Sebastian (ca. 1614). Oil on canvas, $200 \times 128 \mathrm{~cm}$. Gemäldegalerie, Staatliche Museen zu Berlin, Berlin. 


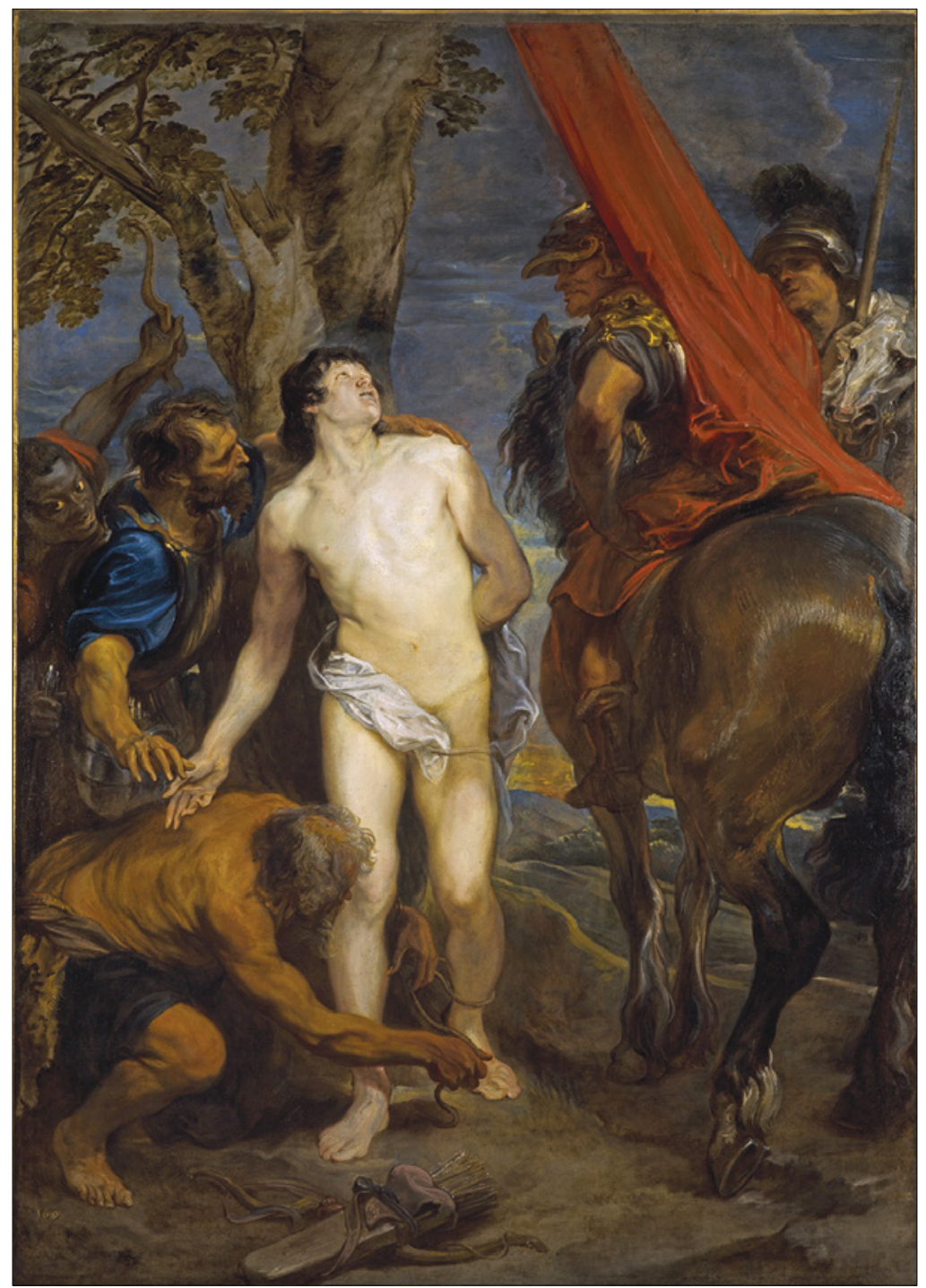

Fig. 4: Anthony Van Dyck, Saint Sebastian Bound for Martyrdom (ca. 1621). Oil on canvas, $223 \times 160 \mathrm{~cm}$. National Gallery of Scotland, Edinburgh, 121. By permission of the Scottish National Gallery. 
Van Dyck, on the other hand, chose to depict a rather unusual episode from the saint's martyrdom, when he was being tied to a tree. The motif of the black attendant has been added on the extreme left, his body pressing against the back of the soldier who pulls Sebastian towards the tree. The African man is cast in the role of an executioner:his arms outstretched, he holds in his raised left hand the bow and in the other hand the arrows with which Sebastian is about to be shot.

While the figure of the saint is based on Titian's Saint Sebastian ${ }^{21}$, the idea to include an African executioner may have been inspired by Rubens's conception of martyrdom scenes as exemplified in The Martyrdom of Saint Stephen. ${ }^{22}$ But whereas Rubens made the black figure form part of a larger crowd intent on killing the saint, Van Dyck downplayed his participation in the execution by making him only the bearer of the instruments of death. This change in character was necessitated by the idea to turn the black attendant into a messenger. As in The Continence of Scipio he turns his head looking out towards the viewer to comment on the scene enacted. In the present context, however, his gleeful face appears to be a rather incongruous element.

The central theme of the painting is the transcendent power of the Christian faith (Wheelock et al. 1990:140). The light beaming down on Sebastian is the light of Christ which the Roman soldiers fail to see. In $17^{\text {th }}$-Century Antwerp the Jesuits used the symbolism of light to enhance the triumph of true religion the light of Truth. Black, in contrast, was identified with the forces of darkness (Massing 2011:316). In this case the aim of the artist was to highlight the folly of non-Christians for living in spiritual darkness. This assumption is underscored by the extreme paleness of Sebastian's skin in comparison with the Roman soldiers. The blackness of the executioner evidently ranks him as the epitome of paganism. Moreover, Van Dyck portrayed the African non-believer with a grin on his face, mocking the Christian faith of Sebastian. This creative modification of the motif of the African attendant parallels the unconventional pose of the saint as an elegant, non-heroic male nude. ${ }^{23}$ According to Adam Eaker (2015:173, 182), the novel concept of Saint Sebastian Bound for Martyrdom advertised Van Dyck's ambition to distinguish himself from the older master by proposing "an aesthetic alternative to Rubens". His deviation from artistic tradition must also be seen in light of the fact that the painting was made for domestic consumption, not destined for public, sacred display in a church

21 There was a copy of Titian's Saint Sebastian in the Earl of Arundel's collection which Van Dyck certainly visited during his English trip in 1620-1621 (Brown 1982:43).

22 Peter Paul Rubens, The Martyrdom of Saint Stephen (ca. 1615-20). Oil on canvas, $437 \times 280 \mathrm{~cm}$. Musée des Beaux-Arts, Valenciennes (Vlieghe 1973, vol. II:150-52, cat. no. 146, fig. 112).

23 Adam Eaker (2015:173) recognises the face of the artist in the martyred saint. His interpretation provides particular insight into Van Dyck's perception of his position in the studio of Rubens. 
(Eaker 2015:181). Hence the artist was at liberty to add a motif that church authorities may have found objectionable.

Van Dyck used the trope of the black attendant once more in a religious theme. Painted in Genoa around 1625 or 1626 (Brown 1982:121), the Man of Sorrows (Fig. 5) shows the captive Jesus in the company of a grinning black bystander holding a cloak around him. While the sorrow of Jesus reflects Van Dyck's study of Titian's treatment of the theme (Barnes et al. 2004:156), the motif of the African attendant is clearly based on the black executioner in Saint Sebastian Bound for Martyrdom. Here again the pale nakedness of Christ is accentuated by the darkness of both the cloak and the African figure which brings the symbolism of light into play. Just as the black executioner did not actively torture Saint Sebastian, the black tormentor of Christ is shown here in an apparent gesture of compassion. Yet the grin on his face once again betrays him as a foolish non-Christian who is blind to the light of Christ. ${ }^{24}$ Since the black attendant is not looking at the viewer but at Christ himself, the scene is turned into an illustration of the mocking of Christ. ${ }^{25}$ Once again the depiction of the black African as a laughing fool was permissible due to the conditions of display. Like the Saint Sebastian Bound for Martyrdom this devotional image was made for private use: it belonged to Francesco Maria Balbi of Genoa. ${ }^{26}$ Balbi may have insisted on the inclusion of a black figure because it was a fashionable feature among the Genoese aristocracy. ${ }^{27}$

\section{Portraits}

The first portrait by Van Dyck featuring a black servant is the one of George Gage with Two Attendants (ca. 1622) (Fig.6). The main subject of the portrait is the Englishman George Gage, who was an agent for Sir Dudley Carleton in collecting art abroad. Interestingly Gage met Van Dyck in Rubens's studio as early as 1616-17 and may have been instrumental in bringing Van Dyck to London in 1620-21 (Barnes et al. 2004:187-88). The artist painted the portrait very soon after his arrival in Rome, in February 1622, before Gage ended his Roman sojourn in July 1622 (Barnes et al. 2004:188).

The portrait was ambitious and innovative in its informal quality, capturing the sitter in a momentary movement of conversation (Barnes et al. 2004:188).

24 In the Christian tradition the fool is a person who does not know God (Verberckmoes 2011:97).

25 Brown (1982:120-21) more aptly entitles the work The Mocking of Christ.

26 The painting appears in the 1701 inventory of the collection of Francesco Maria Balbi of Genoa (Barnes et al. 2004:156).

27 Kaplan (2010:176-80, fig. 91) refers to the painting by Guillem van Deynen of a Group Portrait of Doge Agostino Doria with his Family and Servants (ca. 1601-03) to support this claim. 


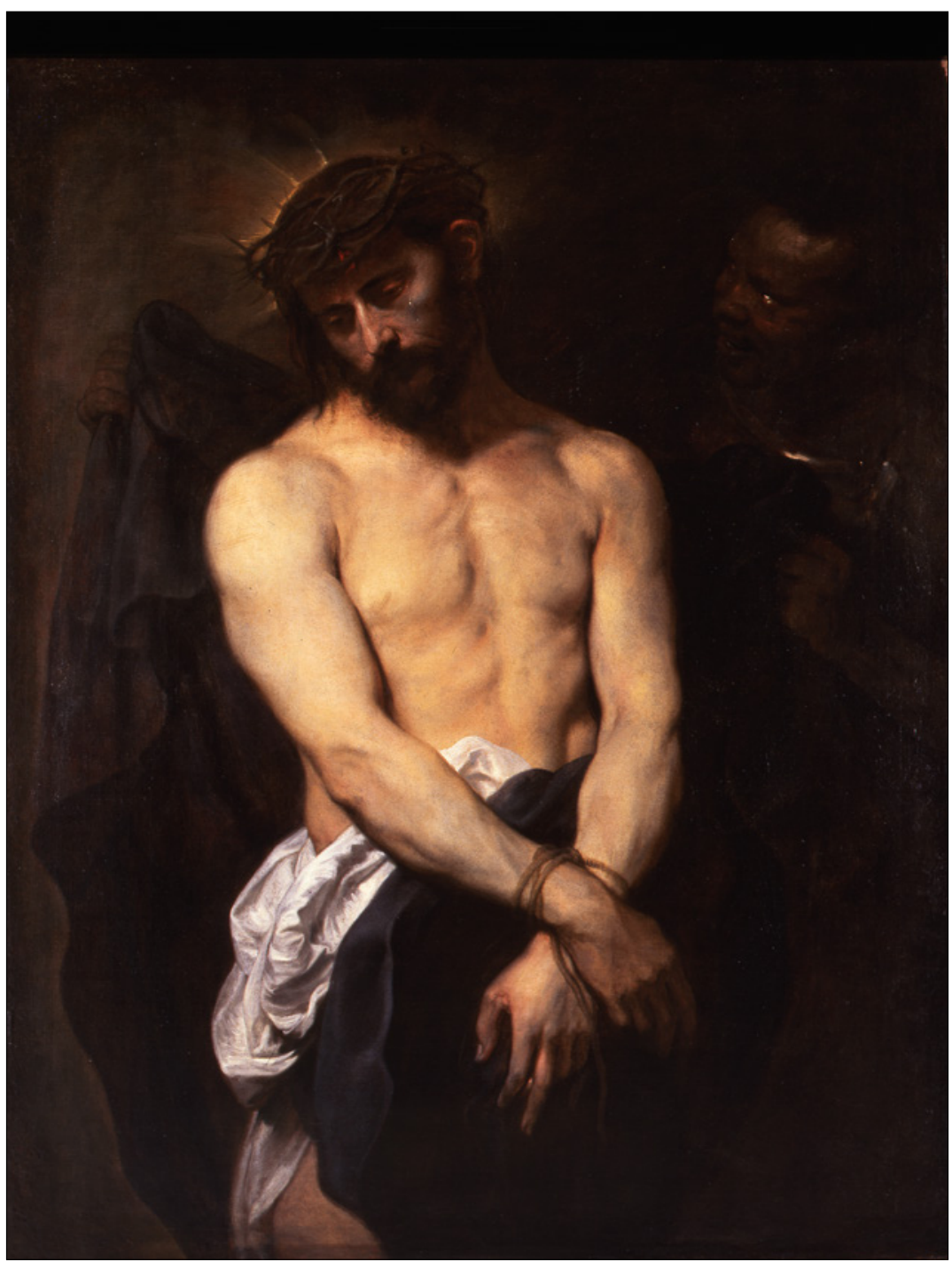

Fig. 5: Anthony Van Dyck, Man of Sorrows (ca. 1625-26). Oil on canvas, 101,5x 78,5 cm. Barber Institute of Fine Arts, Birmingham, 217. The Henry Barber Trust $\odot$ The Barber Institute of Fine Arts, University of Birmingham. 


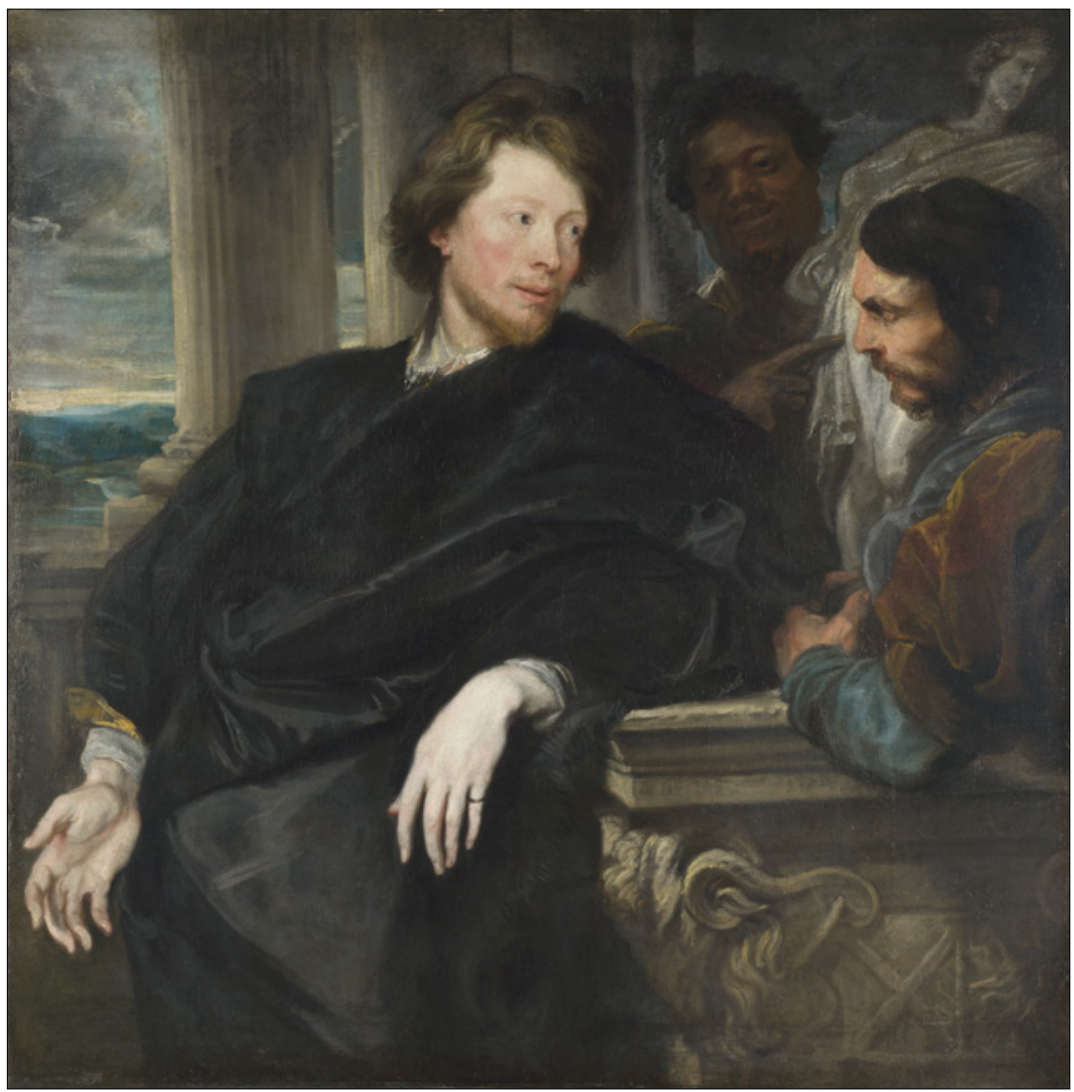

Fig: 6. Anthony Van Dyck, George Gage with Two Attendants (ca. 1622). Oil on canvas, 115 x 113,5 cm. National Gallery, London, NG49. Photo @ The National Gallery, London.

David Bindman (2010:250) describes it as "a bargaining encounter between Gage, on the left, and a dealer offering him a classical statue". The statuette has been identified as a smaller version of the Aphrodite which is one of the Arundel marbles now in the Ashmolean Museum (Gilman 2000:306). Gage leans languidly on a stone pedestal, his head turned towards the dealer and his elegant hands gesticulating in a manner that matches his facial expression. Stewart (1990:70) noted Van Dyck's witty invention to integrate the sitter's coat-of-arms in the relief decoration of the pedestal and to place the ram, the crest of the Gage family, at the corner of the plinth. Further back in between Gage and the dealer appears 
a sturdy dark-skinned servant who points with his right hand to the statue while looking straight at the viewer and "grinning cynically" (Bindman 2010:250).

The significance of this black servant in the context of a portrait seems quite puzzling. In Bindman's (2010:250) opinion, "he seems to anticipate the common eighteenth-century trope of the black as the innocent and astonished observer of the manners of supposedly sophisticated Europeans". According to Ernest Gilman (2000:307), on the other hand, the painting is about "the handing over of the goddess from the dark man whose origins lie on the geographical periphery whence she herself comes, to the middleman who will place her in the hands of Gage ...". He interprets it as "an image of a transmission as well as a transaction, of the removal of the old gods to their new habitation". He thus invests the dark man with allegorical meaning by prioritising his exotic connection with the goddess. ${ }^{28}$ I propose an alternative reading of the black servant which is grounded in the historical context, more specifically the personal relationship between the artist and the sitter. It is also in line with the black man's appearance in earlier works by Van Dyck as a commentator and moralising agent.

The scene is set in Italy - where slavery was commonly practised - hence the fact that the art dealer made use of a strong black servant or slave to handle the heavy statue is not at all unusual. It actually enhanced his status as merchant. The grinning servant points emphatically to the piece of antique sculpture which is the object of negotiation. On closer inspection there are clear correspondences between the classical statue and George Gage in both posture and dress. Their bodies are slanted to the right, their right arms are slightly lifted and their faces are turned to the right. Like the cloak which is draped loosely and elegantly over Gage's left shoulder, a swath of drapery is arranged over the statue's left shoulder. Even their hair style looks similar. This repetition of visual forms establishes a clear link between the main sitter and the classical statue. ${ }^{29}$ Apparently as a result of his extensive travels in Italy over the years Gage had become thoroughly familiar with the Italian ways and had adapted "the ease, the grace, the aplomb - in sum, the sprezzatura [nonchalance] - that was the essential quality of the Italian courtier" (Wheelock et al 1990:160). By turning the sitter into an imitation of the classical statue Van Dyck mocked the Italian mannerisms of the Englishman. He used the black servant as a grinning commentator to make his humorous intentions very clear. Probably the two men had developed a friendly relationship since their first meeting in Antwerp which explains why the artist felt at liberty to poke fun at George Gage.

28 Gilman (2000:307) identifies the goddess as the object that "visually connects the exotic background of the painting denizened by the black servant with the European foreground".

29 Gilman (2000:307) also notes the resemblance between Gage and the statue and reads it as "Gage almost seem[ing] to pose himself as a work of art (in the same measure as the goddess almost seems to come to life)". 
The following year when he was in Genoa, Van Dyck was commissioned by Giacomo Cattaneo to paint a portrait of his wife Elena Grimaldi (Barnes et al. 2004:189). Faced with the fact that she was a noble woman he revised the trope of the African servant and adapted it to the sitter's personal circumstances. The portrait of Marchesa Elena Grimaldi (1623) (Fig. 7) shows the aristocratic patron standing on the terrace of her palace in the company of a black page who holds a red parasol above his mistress's head. Given Genoa's involvement in the slave trade it is most likely that the boy was part of the sitter's household (Massing 2011:225). Since the black page was an ostensible sign of Genoese artistic and social fashion (Kaplan 2010:180), Elena may have insisted that he be incorporated in the portrait in order to highlight her social standing. The idea to present the sitter in the company of a young African was first realised by Titian in his portrait of Laura Dianti. ${ }^{30}$ We know that Van Dyck was infatuated with Titian's works and the fact that an engraving by Aegidius Sadeler and several painted versions of the Laura Dianti were in circulation after 1598 explain the artist's access to the image (Kaplan 2010:180). The concept of Van Dyck's portrait proved entirely innovative in that he combined the informal, momentary quality of Titian's half-length portraits with the grandeur of full-length court portraits by Elena's graceful forward movement (Barnes et al. 2004:189-90).

Barnes describes the page as having "an other-wordly quality" and showing a reverent expression which "functions in the painting to exalt his mistress to an almost supernatural status" (Wheelock et al. 1990:176). Looking closely, the young servant appears to have long pointed ears like those of a satyr - a feature which does indeed render him "other-worldly". While Jean Michel Massing vaguely relates the motif to "antiquarian discussions" 31 there is a more direct reference at hand in the oeuvre of Rubens, namely his painting of Nature Adorned produced in his Antwerp studio in 1615. ${ }^{32}$ Here Silenus is portrayed in the company of a laughing black man with satyr-like ears. According to McGrath, this motif refers to the story of a satyr living in Ethiopia who, on advice of Apollonius, was tamed by the villagers by feeding him wine (Philostratus 6.27). She maintains that Rubens included Ethiopians as followers of Bacchus on account of their association "with natural exuberance and fecundity, the gifts of Nature and the Earth" (McGrath 2006:117).

30 Titian, Laura Dianti (ca. 1523-29). Oil on canvas, $119 \times 93 \mathrm{~cm}$. Collection H. Kisters, Kreuzlingen.

31 According to Massing (2011:223), long pointed ears "were supposedly an attribute of good servants [but] the implication may be something subtler, referring to antiquarian discussions in the artist's circle".

32 Peter Paul Rubens and Jan Brueghel, Nature Adorned (ca. 1615). Oil on panel, 106,7 x 72,4 cm. Art Gallery and Museum, Glasgow. 


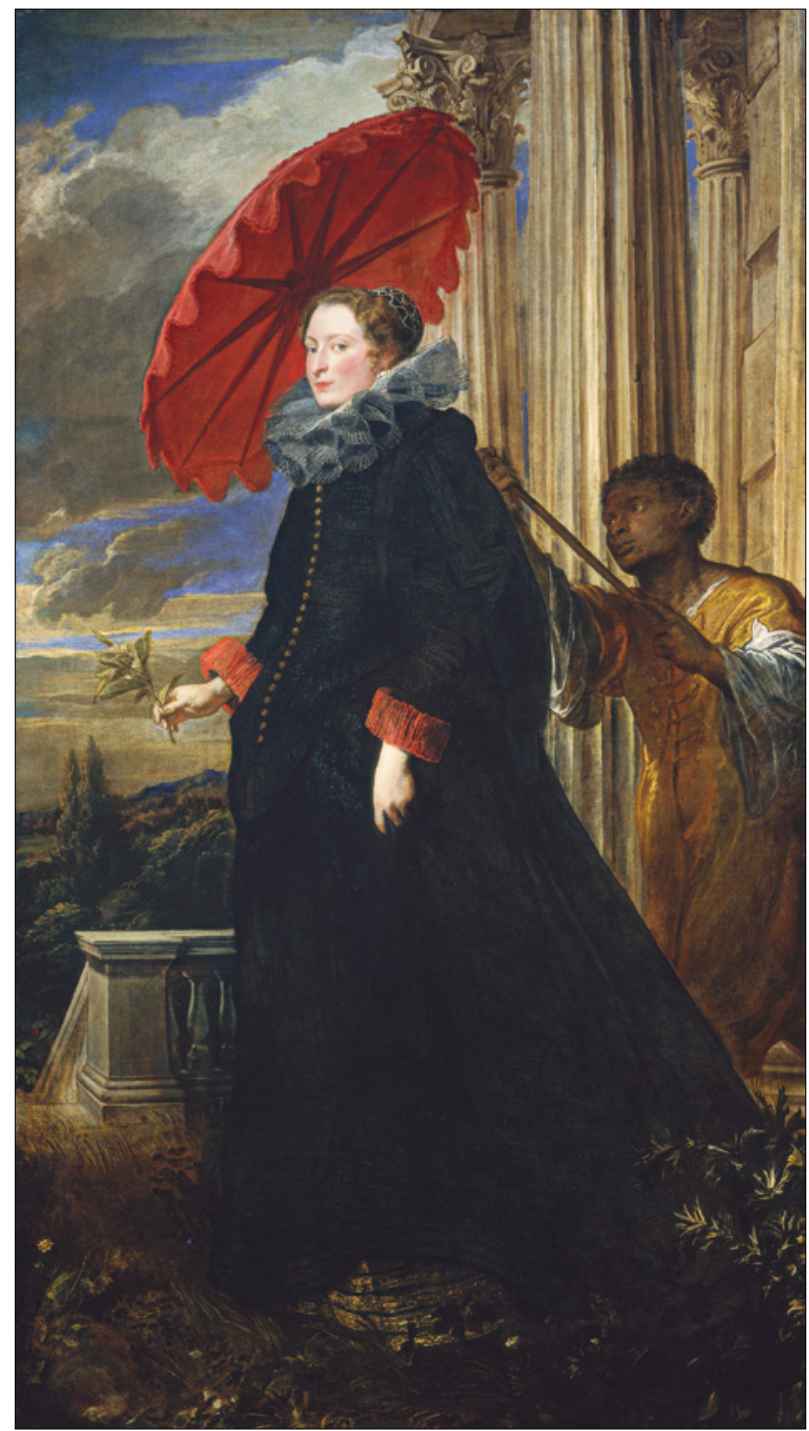

Fig. 7: Anthony Van Dyck, Marchesa Elena Grimaldi (1623). Oil on canvas, 246 x $173 \mathrm{~cm}$. National Gallery of Art, Washington, 1942.9.92. Artwork in the public domain. Courtesy National Gallery of Art, Washington. 
This association makes absolute sense in the context of a celebration of the Great Mother. Surprisingly in the case of Elena Grimaldi the classical reference to the Ethiopian satyr may have similar connotations: the cuffs of Elena's dress are red and so is the parasol - red being a colour that signifies the sitter's pregnancy (Barnes et al. 2004:190). Originally there was a red flower in the sitter's hair which Van Dyck painted out; contour adjustments to the right hand have also been observed (Christensen 1990:48). Apparently the artist substituted the red flower with a sprig of orange blossoms in Elena's right hand. These orange blossoms have been interpreted as a traditional symbol of chastity 33 but the meanings given to flowers are never fixed. ${ }^{34}$ In this particular instance the blossoming stage should rather be seen as the botanical equivalent of human pregnancy. This hypothesis is supported by the fact that when Van Dyck painted the portrait of Elena Grimaldi's daughter Maddalena Cattaneo ${ }^{35}$ in 1623, he depicted the little girl with a fully grown orange in her hands, implicating the end of the cycle of procreation. In view of these references to pregnancy - not least her explicitly swollen abdomen - it is safe to state that the black page is more than just a marker of social status. Through the subtle but witty reference to the Ethiopian satyr as a symbol of fecundity the black page serves to comment on, protect and celebrate the blessed state of the sitter.

After Van Dyck left Italy for Flanders he seems to have lost interest in the motif of the black attendant and did not use it again except in some later court portraits when he was instructed to do so. ${ }^{36}$ During the winter of 1634-35 he spent some time in Brussels painting portraits of Flemish and foreign nobles living near the Brussels court (Vlieghe 1994:201-2). One of these foreign nobles was Princess Henriette of Lorraine, the widow of the prince of Pfalzburg and Lixheim (Wheelock et al. 1990:278-80). Her husband, Louis de Lorraine-Guise, was killed in battle in 1631 and on 8 March 1634 Henriette fled from the French advance on Nancy to Brussels (Barnes et al. 2004:330; Massing 2011:225). Henriette and her sister Margaret of Lorraine were both in exile in Brussels when Van Dyck painted their portraits in 1634 (Massing 2011:225). The full-length court portrait

33 This explanation appears on the National Gallery's website: http://www.nga.gov/content/ ngaweb/Collection/art-object-page.1231.html (accessed August 29, 2015).

34 Paul Taylor (1995:55) warns that "no account of the meanings given to flowers can be in any way complete, since so many of them went unrecorded; used, and then, in all likelihood, quickly forgotten".

35 Anthony Van Dyck, Maddalena Cattaneo (1623). Oil on canvas, $122 \times 84 \mathrm{~cm}$. National Gallery of Art, Washington.

36 Van Dyck did not make portraits with black pages in his English period (1632-1641) (Bindman 2010:249-50). 
of Henriette de Lorraine ${ }^{37}$ shows her in the company of a black page who has, in comparison with Elena Grimaldi's servant, been reduced to a small boy.

The recently widowed sitter wears an exquisite, white embroidered petticoat and black dress which contrasts sharply with the bright red outfit of the black boy. The gold brocade of the background is repeated in the page's gold earrings - a wellestablished attribute of Africans (Kaplan 2010:109) - and a heavy gold chain worn diagonally across the chest. The boy turns his head sideways in order to look up at his mistress. The adoring upward look is derived from Titian's Laura Dianti as is the gesture of the woman resting her hand affectionately on the boy's shoulder. Kaplan (2010:109) maintains that the potent influence of Titian's painting "rests in large part on the flattering effect of effortless mastery that the woman seems to exert over the page". Van Dyck further enhanced the notion of the boy's subservience by pushing him behind the woman, making him only partly visible. Casting the black page in "a marginal, metaphorically invisible role" is a strategy to enforce the woman's white dominance and superiority (Erickson 2009:27, 34). However, as Hondius (2014:5) remarks, "racial paternalism has the assumption of not only superiority but also care". The woman's caring for the infant adds a positive note to her attitude towards black Africans.

Van Dyck introduced additional symbolism to bring home his message. A new element is the page's offering of a gilt platter with pink roses, apparently picked from the garden seen in the background. Roses in Van Dyck's portraits have many different meanings (Filipczak 1990:64). In the present context the flower is symbolic of the beauty of the sitter whose colouring and skin texture are similar to those of a rose (Filipczak 1990:65). Through the addition of this attribute the black page pays tribute not so much to Henriette's wealth and nobility as her beauty. ${ }^{38}$ Erickson (2000:322) specifies the woman's beauty as her "primary whiteness" which is enhanced by the servant's blackness - a connection made visibly clear by the juxtaposition of his small head and her large white hand on his shoulder. Seeing that the portrait of Henriette de Lorraine was commissioned ${ }^{39}$ for the collection of King Charles I both the artist and the sitter would have ensured to stress all her assets to best effect. In this formulation of the motif of the black attendant Van Dyck's paternalism has reached its fullest expression by

37 Anthony Van Dyck, Henriette de Lorraine (1634). Oil on canvas, 213,4 x $127 \mathrm{~cm}$. Inscribed (lower left): Henrietta / Lotharinga Princeps de Phalsburg, 1634 and (lower right): Ant. Van Dyck Eques Fecit. The Iveagh Bequest, Kenwood (Bindman and Gates 2010:252, fig. 136).

38 Filipczak (1990:65) maintains that "whatever other significance such portraits might have, they were always lessons in beauty".

39 The painting was commissioned either by Henriette who gave or sold it to Endymion Porter weeks or months later, or by Porter himself as a gift for Charles I (Barnes et al. 2004:329-30). 
reducing the black servant to an infant who is only partly visible and has become "an appurtenance himself like the things he bestows" (Erickson 2009:33).

\section{A pastoral idyll with a black woman}

All the paintings considered so far feature a black boy or man. Only once did Van Dyck depict a dark-skinned woman, namely in the painting of Amaryllis and Mirtillo (Fig. 8), an illustration of an episode from Giovanni Battista Guarini's pastoral tragicomedy II pastor fido (1590). The story line is as follows:

$[A] n$ oracle had proclaimed that Arcadia would be ravaged by plagues unless the fickle nymph Amaryllis, a descendant of Pan, were to unite with a faithful shepherd of divine descent. Silvio, a descendant of Hercules, was not interested in Amaryllis, but the shepherd Mirtillo loved her. In a kissing contest among the nymphs, Mirtillo took part in disguise and received the prize from the judge, who was Amaryllis; but he gave the garland back to her and disclosed his identity. It later transpired that he was Silvio's long-lost brother. Finally the marriage between the lovers saved the country (Barnes et al. 2004:294).

Commissioned by Prince Frederik Hendrik of Orange for his residence in The Hague $^{40}$ the work was executed in the winter of 1631-32 when Van Dyck visited the Dutch court (Wheelock et al. 1990:240-42). He was the first artist in the Netherlands to visualise the story (Barnes et al. 2004:294) hence the invention of the iconography was his own. The scene is set in a clearing in the forest and shows the moment when Mirtillo removes the floral crown to place it on the head of his beloved Amaryllis. The couple is surrounded by nymphs who are either still absorbed in sensual kissing or acknowledge the victory of Mirtillo. Two nymphs enter the scene on the extreme left, preceded by a black woman who strides forward pointing to the central pair while glancing at the couple embracing on the ground. For inspiration Van Dyck relied on two paintings by Titian which he had seen in Italy and copied in his Italian sketchbook (Wheelock et al. 1990:240-42). The primary source was Titian's famous bacchanal The Andrians ${ }^{41}$ whereas the couple in the lower right was derived from his Mars and Venus. ${ }^{42}$

40 The painting was recorded in an inventory of his residence (drawn up in August 1632) as hanging above a fireplace in the prince's dressing room (Barnes et al. 2004:294).

41 Titian, The Andrians (ca. 1523-1525). Oil on canvas, $75 \times 193 \mathrm{~cm}$. Museo del Prado, Madrid.

42 Titian, Mars and Venus (ca. 1530). Oil on canvas, $97 \times 109 \mathrm{~cm}$. Kunsthistorisches Museum, Vienna. 


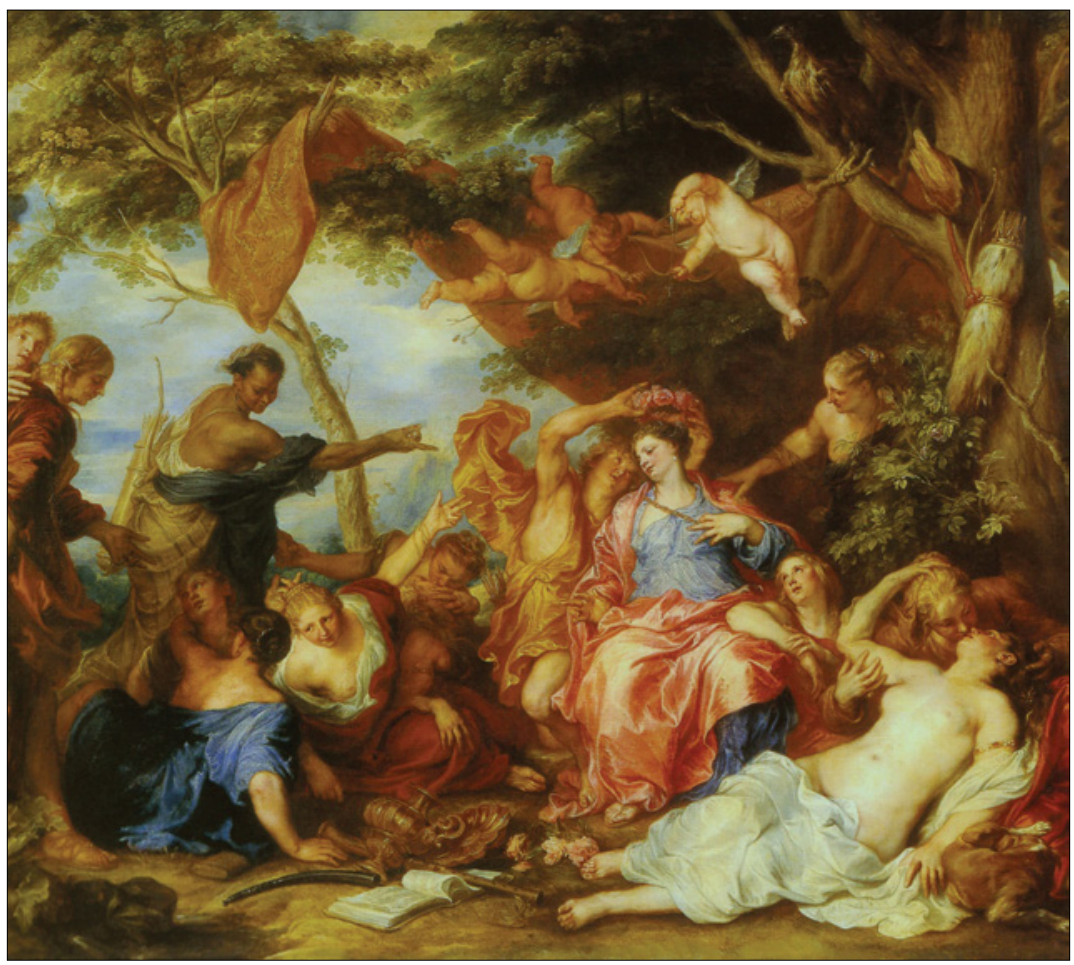

Fig. 8: Anthony Van Dyck, Amaryllis and Mirtillo (ca. 1631-32). Oil on canvas, 123 x137 cm. Kunstsammlungen Graf von Schönborn, SchlossWeissenstein, Pommersfelden, 44. Artwork in the public domain.

The dark-skinned woman, on the other hand, has no precedent and is not even mentioned in Guarini (Barnes et al. 2004:294). The fact that she carries a bow and quiver on her back identifies her as a huntress and relates her to the retinue of Diana, the ancient goddess of the hunt (Hall 1987:101-2). While her chest is mostly uncovered, her lower body is wrapped in a striped garment that marks her as exotic. Unlike the white nymphs who abandon themselves to sensual lesbian games, she is the chaste companion of Diana. This may explain why the artist tried to cover up her nudity by draping a black cloth around her waist and over her right forearm. Her goal is to put an end to the kissing game by pointing out the winner of the contest. She demonstrates this more forcefully by grabbing the palm of the kissing nymph on the ground so as to pull her apart from her partner. 
Although it is clear why the artist needed to differentiate Diana's nymph from the kissing companions of Amaryllis, his choice of a dark-skinned woman is less easily explained. Especially her personification of chastity is at odds with Van Dyck's more typical association of the black figure with sexual desire. The role of the black nymph is also not that of a bystander: shown in isolation and sharply silhouetted against the light blue sky she is accentuated as one of the key players in the scene. What appear to be exceptions to Van Dyck's norms and strategies established so far can, however, be explained with reference to an oil sketch ${ }^{43}$ made in preparation for the Pommersfelden painting (Barnes et al. 2004:293). In this grisaille in reddish-brown and white the artist portrayed Diana's nymph as white and the kissing nymph as black in line with his usual characterisation of the black figure. The sketch thus proves that Van Dyck adapted his original iconography to the preferences of the commissioner. The reversal of the roles of the two women was probably requested by the Prince of Orange's secretary Constantijn Huygens. He had a hand in determining the decorative scheme of Frederik Hendrik's living quarters and was also intimately familiar with Guarini's work (Wheelock et al. 1990:240). This intervention explains why the painting of Amaryllis and Mirtillo constitutes such an anomaly in Van Dyck's oeuvre. Never again did he paint a black woman.

\section{Conclusion}

Stewart (1990:69) claims that "Van Dyck's use of symbols and allusions has often been ignored" alongside the "considerable sense of humour" in these aspects of his art. The African attendant is one of those symbols that testify to the artist's sense of humour. Yet his witty allusions were at times so troubling and risqué that they have indeed been continuously overlooked in Van Dyck scholarship. Or, one could argue, they have been purposefully avoided on account of the sometimes blatant paternalism evident in the artist's representation of the black African that could be interpreted as racial prejudice. Having examined various works featuring a black attendant it is clear that Van Dyck's use of the trope was motivated by aesthetic concerns, issues of patronage and display, social ambitions and religious values. Depending on a combination of these factors he would adjust his articulation of the black attendant without, however, ever abandoning his patronising tone.

From an aesthetic angle Van Dyck based his depiction of the black figure on the examples set by Titian and Rubens. While emulating illustrious precedents

43 Anthony Van Dyck, Amaryllis and Mirtillo (ca. 1628-29). Oil on panel, 23,1 x 35,5 cm. École Nationale Supérieure des Beaux-Arts, Paris, 11704. 
his ambition drove him to make changes in order to develop his own aesthetic canon and personalised imagery. One way of doing this was by manipulating the nature of the African attendant according to the specific theme at hand. In his history paintings he used the black adult in a pagan state - that is, before his conversion to Christianity - to personify all things non-Christian such as excessive drinking, womanising and cruelty. By means of explicit gestures and facial expressions and, more overtly, by carrying significant objects the black attendant, though visually marginal, became a theatrical performer who played a strategic role in reinforcing the moral implications of the scene. Similarly in his portraits the African servant, although more demure, carried meaning literally as a bearer of objects which refer to the personal characteristics and circumstances of the sitter. In the final stage of the development of the trope of the black servant Van Dyck turned him into a harmless young boy whose devotion to his mistress reflects his unwavering Christianity. In all instances the nature and extent of the artist's adaptations of the motif were determined by the expectations of the patron and the conditions of display. These strategies of representation resulted in original conceptualisations of the black African which set Van Dyck far apart from his Flemish contemporary Rubens.

Van Dyck's typecasting of the black African was also shaped by contemporary ideas about blackness. The European perception of black Africans in the $17^{\text {th }}$ Century has been construed as a function of social and aesthetic fashion - the ornamental display of the exotic - as well as of theology (Erickson 1993:501-2). In Van Dyck's portraits the inclusion of an African servant was more readily motivated by a concern with social and aesthetic fashion. The sitters would have insisted on the portrayal of an exotic servant as a marker of their social status and their beauty. When conceiving his history paintings, religious values may have played a more crucial role in the construction of an African identity. In the time of the Counter-Reformation black people were seen to represent the Gentiles who were ready to recognise and accept Christ. Hence from a theological perspective African blackness was a signal of "openness to the Christian message" (McGrath 2008:52). The generally positive perception of Africans was, however, characterised by a definite ambivalence which persisted throughout the centuries (Blakely 1993:276). Even though Van Dyck was a deeply religious person (Stewart 1990:69), this ambivalence becomes particularly pertinent in his shifting portrayal of the black attendant.

Certainly Van Dyck's personal engagement with African models must have contributed to this ambivalent attitude which can best be described as racial paternalism. The confrontation with the vastly different culture of black Africans led to patronising behaviour on the part of the white artist who felt superior to this ethnic other. Various patterns of paternalism identified by Hondius can be 
recognised in Van Dyck's works. Distancing is the most common strategy found in both his history paintings and portraits: the black attendant is always removed from the focal point into the background or towards the periphery and thus rendered less visible. ${ }^{44}$ Exoticism is apparent in the representation of the black African as "extraordinary, fascinating, exciting, beautiful, endearing, attractive, and adorable, with a hint of danger" (Hondius 2014:4). The latter qualities are the result of another strategy, namely infantilisation which is visually translated in the reduction of the black attendant to a small boy. In the history paintings, however, it is ridicule that is the dominant pattern of paternalism. Because black Africans were experienced as a minority group, in this case easily recognisable as an ethnic other, their presentation as exemplars of undesirable behaviour could elicit mirth and amusement in those who belonged to the central majority. By mocking the other, Van Dyck at once consolidated the moral values of the social elite of which he was a member while rendering the African minority less threatening and also more dependent on the white majority .

Van Dyck's interest in the trope of the African attendant was, however, not long-lasting. He tested the symbolic potential of the motif for roughly five years and then abandoned it in the mid-1620s. His particular brand of racial humour observed in the works discussed here apparently did not appeal to artists in the $17^{\text {th }}$ Century, presumably because the black presence was too limited to elicit a shared response. What the artists were looking for was a formula that would be inoffensive, flattering and aesthetically pleasing. Almost a decade later Van Dyck invented the ideal stereotype in his portrait of Henriette de Lorraine as it set the standard for a new fashion. Significantly it features the most docile and positive of Van Dyck's black Africans, the baptised young boy serving his white mistress.

\section{Acknowledgement}

This research was made possible by a Foreign General Research Grant from the College of Human Sciences, University of South Africa. Please note, however, that any views or findings expressed in this article are my own.

\section{Bibliography}

Barnes SJ, De Poorter N, Millar O and Vey H (2004) Van Dyck.A complete catalogue of the paintings. New Haven and London: Yale University Press.

44 Closely related to the desire to keep black Africans at a distance is the visual dynamic of selective visibility in portraiture observed and discussed by Erickson (2009:24). 
BARNES SJ AND WHEELock AK JR (eds) (1994) Van Dyck 350. Washington: National Gallery of Art.

BINDMAN D (2010) The black presence in British art: sixteenth and seventeenth centuries. In: Bindman D and Gates HL Jr (eds) The Image of the Black in Western Art. From the 'Age of Discovery' to the Age of Abolition: Artists of the Renaissance and Baroque. Vol. III, no. 1. Cambridge: Harvard University Press.

BINDMAN D AND GATES HL JR (eds) (2010) The image of the black in western Art. From the 'age of discovery' to the age of abolition: Artists of the Renaissance and Baroque. Vol. III, no. 1. Cambridge: Harvard University Press.

BINDMAN D AND GATES HL JR (eds) (2011) The image of the black in western art. From the 'age of discovery' to the age of abolition: Europe and the world beyond. Vol. III, no. 2. Cambridge: Harvard University Press.

BLAKELY A (1993) Blacks in the Dutch world: the evolution of racial imagery in a modern society. Bloomington and Indianapolis: Indiana University Press.

BROWN C (1982) Van Dyck. Oxford: Oxford University Press.

Christensen C, PALmer M AND SWICKLIK M (1990) Van Dyck's painting technique, his writings, and three paintings in the National Gallery of Art. In: Wheelock AK, Barnes SJ and Held JS (eds) Van Dyck Paintings. London: Thames and Hudson.

DAVIES C (1982) Ethnic jokes, moral values and social boundaries. The British Journal of Sociology 33(3):383-403. https://doi.org/10.2307/589483.

De Clippel K, Van Cauteren K and Van Der Stighelen K (eds). The nude and the norm in the early modern Low Countries. Turnhout: Brepols.

EAKER A (2015) Van Dyck between master and model. The Art Bulletin 97(2):17391. https://doi.org/10.1080/00043079.2015.979087

ERICKSON P (1993) Representations of blacks and blackness in the Renaissance. Criticism 35(4):499-528.

ERICKSON P (2000) "God for Harry, England, and Saint George": British national identity and the emergence of white self-fashioning. In: Erickson P and Hulse C (eds) Early modern visual culture: Representation, race, and empire in Renaissance England. Philadelphia: University of Pennsylvania Press.

ERICKSON P (2009) Invisibility speaks: Servants and portraits in early modern visual culture. Journal for Early Modern Cultural Studies 9(1):23-61. https:// doi.org/10.1353/jem.0.0027

ERICKSON P AND HULSE C (eds) Early modern visual culture: Representation, race, and empire in Renaissance England. Philadelphia: University of Pennsylvania Press.

FAIRFAXB (1758) A catalogue of the curious collection of pictures of George Villiers, Duke of Buckingham. London. 
FILIPCZAK ZZ (1990) Reflections on motifs in Van Dyck's portraits. In: Wheelock AK, Barnes SJ and Held JS (eds) Van Dyck Paintings. London: Thames and Hudson. GILMAN EB (2000). Madagascar on my mind: The Earl of Arundel and the arts of colonization. In: Erickson P and Hulse C (eds) Early modern visual culture: Representation, race, and empire in Renaissance England. Philadelphia: University of Pennsylvania Press.

HALL J (1987) Dictionary of subjects and symbols in art. London: John Murray.

HELD JS (1980) The oil sketches of Peter Paul Rubens. A critical catalogue. 2 vols. Princeton, New Jersey: Princeton University Press.

HELD JS(1994) Van Dyck's relationship to Rubens. In: Barnes SJ and Wheelock AK Jr (eds) Van Dyck 350. Washington: National Gallery of Art.

HondIUS D (2014) Blackness in Western Europe: Racialpatterns ofpaternalism and exclusion. New Brunswick (USA) and London (UK): Transaction Publishers.

JERVIS S (1997) Furniture for the First Duke of Buckingham. Furniture History 33:48-74.

KAPLAN PHD (2010) Italy, 1490-1700. In: Bindman D and Gates HL Jr (eds) The Image of the Black in Western Art. From the 'Age of Discovery' to the Age of Abolition: Artists of the Renaissance and Baroque. Vol. III, no. 1. Cambridge: Harvard University Press.

KAPLAN PHD (2015) Bartolomeo Passarotti and "Comic" Images of Black Africans in Early Modern Italian Art. In: Rosenthal A, Bindman D and Randolph A (eds) No laughing matter: Visual humor in ideas of race, nationality and ethnicity. Dartmouth: Dartmouth College Press.

KosLowS (1995) Frans Snyders: peintreanimalier et de natures mortes 1579-1657. Antwerp: Fonds Mercator Paribas.

MASSING JM (2011). In: Bindman D and Gates HL Jr (eds) The image of the black in western art. From the 'age of discovery' to the age of abolition: Europe and the world beyond. Vol. III, no. 2. Cambridge: Harvard University Press.

MCGRATH E (2006) Garlanding the Great Mother: Rubens, Jan Breughel and the celebration of nature's fertility. In: Van der Stighelen $K$ (ed) Munusculaamicorum. Contributions on Rubens and his colleagues in honour of Hans Vlieghe. Turnhout: Brepols.

McGRATH E (2008) Goltzius, Rubens and the beauties of the night. In: Schreuder E and Kolfin E (eds) Black is beautiful: Rubens to Dumas. Zwolle: Waanders; various catalogue entries.

MEYER JC (2000) Humor as a double-edged sword: Four functions of humor in communication. Communication Theory 10(3):310-331. https://doi. org/10.1111/j.1468-2885.2000.tb00194.x

MorReAL J (ed) (1987) The philosophy of laughter and humor. Albany: State University of New York Press. 
RobeLS H (1989) Frans Snyders: Stilleben- und Tiermaler 1579-1657. Munich: Deutscher Kunstverlag.

RoSENTHAL A, BINDMAN D AND RANDOLPH A (eds)(2015) No laughing matter: Visual humor in ideas of race, nationality and ethnicity. Dartmouth: Dartmouth College Press.

SteWART JD (1990) "Death Moveth Not His Generous Mind": Allusions and ideas, mostly classical, in Van Dyck's work and life. In: Wheelock AK, Barnes SJ and Held JS (eds) Van Dyck Paintings. London: Thames and Hudson.

TAYLOR P (1995) Dutch flower painting 1600-1720. Yale: Yale University Press.

VAN DER Stighelen K (1994) Young Anthony: Archival discoveries relating to Van Dyck's early career. In: Barnes SJ and Wheelock AK Jr (eds) Van Dyck 350. Washington: National Gallery of Art.

Van Der Stighelen K (ed) (2006) Munuscula amicorum. Contributions on Rubens and his colleagues in honour of Hans Vlieghe. Turnhout: Brepols.

VAN HAUTE B (1999) David III Ryckaert: A seventeenth-century Flemish painter of peasant scenes. Turnhout: Brepols.

VAN HAUTE B (2015) Black tronies in seventeenth-century Flemish art and the African presence.de arte 91:18-38.

VERBERCKMOES J (2011) Is that flesh for sale? Seventeenth-century jests on nudity in the Spanish Netherlands. In: de Clippel K, Van Cauteren K and Van der Stighelen K (eds). The nude and the norm in the early modern Low Countries. Turnhout: Brepols.

VLIEGHE H (1973) Saints. 2 vols. London, New York: Phaidon.

VLIEGHE H (1994) Thoughts on Van Dyck's early fame and influence in Flanders. In: Barnes SJ and Wheelock AK Jr (eds) Van Dyck 350. Washington: National Gallery of Art.

Wheelock AK, Barnes SJ And Held JS (1990) Van Dyck Paintings. Exhibition catalogue. Washington, National Gallery of Art, 11 November 1990 24 February 1991. London: Thames and Hudson. 